\title{
POLA KOMUNIKASI URBAN CARE COMMUNITY PADA MASYARAKAT MARGINAL SURABAYA
}

\author{
Dian Maulana Chandra ${ }^{1}$, Pardianto ${ }^{2}$ \\ ${ }^{1,2}$ Universitas Islam Negeri Sunan Ampel Surabaya \\ 1dianmaulana@gmail.com, 2aan.pardianto08@gmail.com
}

\begin{tabular}{l}
\hline \hline Article Info \\
\hline \\
Received 7 Agustus 2019 \\
Accepted 10 September 2019 \\
Published 5 Oktober 2019 \\
\end{tabular}

Keyword:

Pola Komunikasi, Proses Komunikasi, Masyarakat Marginal

\section{Abstract}

Marginalization still occurs in some communities in the city of Surabaya. One of them is the people in the Kali Jagir village of Surabaya. Urban Care Community is a non-governmental organization (NGO) that fosters marginalized communities in Stren Kali Jagir, Wonokromo, Surabaya City. This article discusses how the Urban Care Community process and communication patterns among marginalized communities in the Kali Jagir Stren. The purpose of this study was to determine the patterns and processes of Urban Care Community communication in empowering marginalized communities in Stren Kali Jagir. This study uses a qualitative descriptive research method. The result of this research is the communication process carried out by the Urban Care Community with marginalized communities in the Kali Jagir Stren using interpersonal communication processes, group communication, and social media communication to make it more efficient. Meanwhile, the communication pattern with marginalized communities in Stren Kali Jagir uses a secondary communication pattern.

Marginalisasi masih terjadi pada beberapa masyarakat di Kota Surabaya. Salah satunya adalah masyarakat perkampungan Stren Kali Jagir Surabaya. Urban Care Community merupakan salah satu Lembaga Swadaya Masyarakat (LSM) yang membina masyarakat marginal di Stren Kali Jagir, Wonokromo, Kota Surabaya. Artikel ini membahas tentang bagaimana proses dan pola komunikasi Urban Care Community pada masyarakat marginal di Stren Kali Jagir. Tujuan penelitian ini adalah mengetahui pola dan proses komunikasi Urban Care Community dalam pemberdayaan masyarakat marginal di Stren Kali Jagir. Penelitian ini menggunakan metode penelitian diskriptif kualitatif. Hasil penelitian ini adalah proses komunikasi yang dilakukan Urban Care Community dengan masyarakat marginal di Stren Kali Jagir menggunakan proses komunikasi antarpribadi, komunikasi kelompok, dan komunikasi bermedia sosial agar lebih efesien. Sedangkan pola komunikasi dengan masyarakat marginal di Stren Kali Jagir menggunakan pola komunikai sekunder.

Copyright $@ 2019$ Jurnal Ilmu Komunikasi

\section{Editorial Office:}

Program Studi Ilmu Komunikasi, Fakultas Dakwah dan Komunikasi, UIN Sunan Ampel Surabaya. Jl. Ahmad Yani 117 Surabaya, Jawa Timur, Indonesia.

Email: jurnalilkom@uinsby.ac.id 


\section{Pendahuluan}

Komunikasi berhubungan dengan perilaku manusia dan kepuasan terpenuhinya kebutuhan berinteraksi dengan manusia-manusia lainnya. Hampir setiap orang membutuhkan hubungan sosial dengan orang-orang lainnya dan kebutuhan tersebut dipenuhi melalui pertukaran pesan yang berfungsi sebagai jembatan untuk mempersatukan manusiamanusia yang tanpa berkomunikasi akan terisolasi. ${ }^{1}$

Manusia berinteraksi dengan sesamanya dalam kehidupan untuk menghasilkan pergaulan dalam suatu kelompok sosial, pergaulan semacam itu akan terjadi apabila manusia dalam hal ini, orang perorangan atau kelompokkelompok manusia yang bekerja sama, saling berbicara untuk mencapai tujuan bersama. $^{2}$

Komunikasi merupakan suatu proses penyampaian ide atau gagasan dari komunikator terhadap komunikan. Komunikasi minimal mengandung kesamaan makna antara dua pihak yang terlibat, dikatakan minimal karena, kegiatan komunikasi tidak hanya informatif, yakni agar orang lain bersedia menerima suatu paham atas keyakinan, melainkan suatu perbuatan atau kegiatan dan lain-lain. ${ }^{3}$

Sama halnya saat berkomunikasi dengan masyarakat marginal yang memiliki latar belakang dan pemikiran

\footnotetext{
1 Deddy Mulyana, Jalaluddin Rahmat, Komunikasi Antar Budaya Panduan Berkomunikasi Dengan Orang-orang Berbeda Budaya, (Bandung: PT Remaja Rosdakarya, 2016), 12.
}

yang berbeda dengan masyarakat umum, sehingga menjadi tantangan tersendiri bagi yang berkomunikasi dengan mereka. Karena pada dasarnya kelompok marginal secara bertahap mengembangkan cara berpikir yang berbeda, sebagai bagian dari upaya membangun karakter dan identitas diri untuk melindungi dirinya dari orang lain yang memojokkan keberadaanya.

Cara berpikir ini dikembangkan berdasar realitas marginalisasi yang yang telah ada sehingga cenderung berprilaku reaktif dan kelompok marginal dipandang sebelah mata oleh masyarakat menengah ke atas. Sehingga kelompok marginal merasa direndahkan. Keadaan inilah yang melatar belakangi terbentunya sebuah komunitas dengan nama Urban Care Community (UCC) yang memiliki kegiatan untuk membina masyarakat marginal di Stren Kali Jagir, Wonokromo, Surabaya.

Urban Care Community lahir dari keprihatinan mereka terhadap kondisi masyarakat marginal Stren Kali Jagir, Surabaya. Perlunya tindakan memanusiakan manusia melalui proses yang disengaja yakni pembinaan masyarakat marginal lewat sebuah program pendidikan. Dalam melaksanakan program, komunitas UCC akan cukup sulit untuk mengikuti pola komunikasi masyarakat marginal Stren Kali Jagir, dilihat dari kepribadian mereka yang sulit ditebak dan susah untuk diajak berubah,

2 Elly, M. Setyadi dkk, Ilmu Sosial dan Budaya Dasar, (Jakarta: Kencana Penanda Media group, 2007), 90.

${ }^{3}$ Onong Uchjana Effendy, Ilmu komunikasi Teori Dan Praktek, (Bandung: Remaja Rosdakarya, 2009), 20. 
sehingga komunitas UCC pasti akan membentuk pola komunikasi tersendiri dengan cara yang berbeda dalam berinteraksi dan mensosialisasikan kegiatan agar masyarakat marginal ikut serta dalam kegiatan yang dibuat oleh komunitas UCC.

Komunitas ini memiliki tujuan untuk menciptakan gerakan solutif bagi masyarakat Kota Surabaya yang termarginalkan, agar peduli terhadap pendidikan sehingga dapat bersaing dengan kehidupan perkotaan. Untuk mencapai tujuan tersebut dibutuhkan proses komunikasi dalam mempengaruhi masyarakat agar bersedia menerima program dari Urban Care Community dan mau diajak bekerjasama dalam mengubah perkampungan Stren Kali Jagir sehingga menjadi lebih baik agar tidak dipandang sebelah mata oleh masyarakat lain Kota Surabaya.

Namun masyarakat yang dibina oleh UCC (Urban Care Community) merupakan masyarakat berbeda, mereka berada di lingkungan yang keras, hidup bersama orang-orang yang memiliki latar belakang pekerjaan yang bermacam-macam seperti pemulung, pengamen jalanan, bahkan mantan PSK. Dengan alasan tingkat perekonomian dan ketrampilan yang rendah, mereka harus bekerja keras untuk menghidupi dirinya dan keluarganya sehingga melahirkan pola berpikir yang berbeda.

Perbedaan dapat dirasakan saat bertemu dengan masyarakat marginal secara langsung, dilihat dari cara mereka berkomunikasi dan bersosialisasi terhadap orang baru. Saat mengajak mereka untuk berinteraksi dan berkomunikasi, seorang komunikator harus memiliki tekni dan cara sendiri agar ada timbal balik dari masyarakat. Meskipun begitu masyarakat marginal di Stren Kali Jagir ini memiliki alasan tersendiri untuk mengikuti dan mepercayai tujuan yang dibangun komunitas UCC.

Pada dasarnya mereka akan berfikir dua kali untuk mengikuti kegiatan yang diadakan UCC, tentu mereka akan mempertimbangkan waktu yang mereka miliki, bagaimana membagi waktu untuk bekerja mencari uang dan mengikuti kegiatan UCC. Maka dari itu UCC harus memiliki strategi tersendiri dalam mengajak dan mempertahankan masyarakat marginal agar ikut serta dalam setiap kegiatan yang mereka lakukan.

Tidak hanya orang dewasa, namun anak-anak di Stren Kali Jagir, Surabaya juga menjadi sasaran komunitas UCC mengingat bahwa anak-anak merupakan generasi bangsa, mereka juga dibina oleh komunitas UCC. Tentu saja tidak mudah mengajak anak-anak ini untuk ikut serta dalam kegiatan yang diadakan oleh komunitas UCC. Dengan latar belakang keluarga dan lingkungannya yang keras tentu mereka mermemiliki komunikasi yang berbeda dengan anak-anak kecil pada umumnya. Jika anak-anak kecil pada umumnya memiliki komunikasi dengan keluarga yang cukup efektif dan tutur bahasa yang baik dan benar, berbeda dengan anak-anak ini yang memiliki tutur bahasa yang kasar.

Dalam melaksanakan program, komunitas UCC akan cukup sulit untuk mengikuti pola komunikasi masyarakat 
marginal Stren Kali Jagir, dilihat dari kepribadian mereka yang sulit ditebak dan susah untuk diajak berubah, sehingga komunitas UCC pasti akan membentuk pola komunikasi tersendiri dengan cara yang berbeda dalam berinteraksi dan mensosialisasikan kegiatan agar masyarakat marginal ikut serta dalam kegiatan yang dibuat oleh komunitas UCC.

Berdasarkan latar belakang diatas, peneliti tertarik untuk meneliti lebih lanjut tentang Proses dan pola komunikasi Urban Care Community dalam mendekatkan diri dengan masyarakat marginal Stren Kali Jagir, Surabaya, sehingga mereka mau mengikuti kegiatan UCC.

\section{Kajian Pustaka}

\section{Makna Komunikasi}

Banyak komunikasi yang terjadi dan berlangsung tetapi kadang-kadang tidak tercapai kepada sasaran dan target tentang maksud apa yang dikomunikasikan sehingga menimbulkan konflik dan ketegangan. Suatu konflik terjadi karena ketidak seimbangan proses komunikasi antara komunikator dengan komunikan sehingga menimbulkan dominasi dan perbedaan kepentingan yang tidak dapat dihilangkan begitu saja.

Melalui komunikasi orang dapat merencanakan masa depanya, mampu membentuk kelompok atau komunitas dan lain-lain. Dengan komunikasi manusia dapat menyampaikan informasi, opini, ide, gagasan, konsepsi, pengetahuan, perasaan, sikap, perbuatan, dan sebagainya kepada sesamanya secara timbal balik, baik

\footnotetext{
${ }^{4}$ A. W. Widjaja, Komunikasi dan Hubungan Masyarakat, (Jakarta: Bumi Aksara, 1993), 5 .
}

sebagai penyampai maupun penerima komunikasi. Dengan berkomunkasi orang dapat mengutarakan berbagai pengalamannya kepada orang yang dikehendaki, sehingga pengalaman itu menjadi milik orang lain pula. Sehingga dengan demikian, akan terbinalah perkembangan kepribadiannya baik sebagai indvidu pribadi maupun komunitas sosial, serta tercapainya pula kehidupan bersama dan bermasyarakat". ${ }^{4}$

Dari apa yang dikatakan terbukti bahwa kegiatan yang dilakukan manusia, seringkali dengan tanpa pikir, sebenarnya merupakan kegiatan yang pokok dalam kehidupan bermasyarakat atau sebagaimana dinyatakan oleh seseorang tokoh komunikasi: bahwa "Communication is human existen and sosial proses". Melalui komunikasi orang dapat mempengaruhi dan mengubah sikap tingkah laku orang lain. Membentuk suatu consensus, yang dikenal sebagai pendapat umum, kelompok. ${ }^{5}$

Terlepas dari apakah komunikasi membangun atau menghamcurkan struktur masyarakat, yang jelas komunikasi adalah suatu fenomena secara nyata, suatu realitas sosial yang mempengaruhi kehidupan sosial manusia yang begitu dekat dan akrab dengan kehidupan manusia, suatu kebutuhan yang tidak dapat dielakkan oleh setiap manusia, sebagai dasar dan inti dari sifat dan status kemanusiaannya. Yang selalu berhubungan, berinteraksi dan

\footnotetext{
${ }^{5}$ A. W. Widjaja, Komunikasi dan Hubungan,
} 
berkomunikasi dengan manusia lainnya, sehingga ia benar-benar manusiawi. ${ }^{6}$

Dengan berkembangnya komunikasi, maka lingkup komunikasi mengalami perubahan yang mendasar dengan sendirinya. Banyak para ahli komunikasi yang menguraikan lingkup komunikasi, namun pada dasarnya perkembangan tidak menyimpang dari konsep diatas. Onong Uchjana Effendy menguraikan secara umum makna komunikasi dapat dilihat dari dua segi yaitu dari segi etimologis dan terminologis. ${ }^{7}$

a. Pegertian komunikasi secara etimogis

Istilah komunikasi atau dalam bahasa inggrisnya Communication, berasal dari bahasa latin communicatio, dan perkataan ini bersumber pada kata communis. Arti communis disini adalah sama, dalam arti kata sama makna mengenai suatu hal. Artinya seseorang melakukan komunikasi apabila seseorang dengan orang lain memiliki kesamaan gagasan atau ide dalam pesan yang disampaikan dengan tujuan agar orang lain memahami apa yang dimaksudkan, sehingga komunikasi dapat berjalan dengan baik dan komunikatif.

b. Pengertian komunikasi secara terminologis

Secara terminologis komunikasi berarti suatu proses penyampaian peryataan atau pesan oleh seseorang kepada orang lain. Dari pengertian itu jelas bahwa komunikasi melibatkan sejumlah orang, dimana seseorang menyatakan sesuatu kepada orang

6 Yoyon Mudjiono, Ilmu Komunikasi, (Surabaya: Jaudar Press, 2015), 3. lain. Jadi yang terlibat dalam komunikasi itu adalah manusia. Karena itu, komunikasi yang dimaksud disini adalah komunikasi manusia atau dalam bahasa asing disebut human communication, yang sering kali juga disebut komunikasi sosial atau social communication.

Komunikasi manusia sebagai singkatan dari komunikasi antar manusia dinamakan komunikasi sosial atau komunikasi kemasyarakatan karena hanya kepada manusiamanusia yang bermasyarakat terjadinya komunikasi. Masyarakat terbentuk dari paling sedikit dua orang yang saling berhubungan dan berinteraksi antar sesamanya dengan komunikasi sebagai penjalinannya.

Jadi, komunikasi adalah proses penyampaian atau penyamaan makna gagasan atau pesan dari seorang komunikator kepada komunikan sebagaimana dalam upaya mempengaruhi atau merubah orang lain agar bertindak sesuai dengan apa yang dikehendaki dengan atau tanpa melalui media.

Komunikasi akan dapat berhasil baik apabila sekiranya timbul saling pengertian, yaitu jika kedua belah pihak si pengirim dan si penerima pesan dapat memahami. Hal ini tidak berarti bahwa keduanya harus menyetuji suatu gagasan tersebut. Yang terpenting adalah kedua pihak sama-sama memahami gagasan tersebut. Maka dalam hal inilah dapat

\footnotetext{
${ }^{7}$ Onong Uchjana Effendy, Ilmu komunikasi,
} 11-12. 
dikatakan bahwa komunikasi telah berhasil.

Sedangkan makna komunikasi secara paradigmatis Dalam pengertian komunikasi secara paradigmatis, komunikasi mengandung arah dan tujuan tertentu, ada yang dilakukan secara lisan, secara tertulis, secara tatap muka, atau melalui media, baik media masa seperti surat kabar, radio, televisi, atau film maupun media non massa, misalnya surat telepon, papan pengumuman, poster, sepanduk, dan sebagainya. Jadi komunikasi dalam pengertian paradigmatis bersifat intensional (intentional) mengandung tujuan, karena itu harus dilakaukan dengan perencanaan. Sejauh mana kadar perencanaan itu, tergantung kepada pesan yang akan dikomunikasikan dan pada komunikan yang dijadikan sasaran. Mengenai pengertian komunikasi secara paradigmatic ini banyak define yang dikemukakan oleh para ahli. ${ }^{8}$

Berdasarkan penjelasan di atas maka penulis menyimpulkan bahwa, Komunikasi adalah proses penyampaian atau penyamaan makna gagasan atau pesan dari seorang komunikator kepada komunikan sebagaimana dalam upaya mempengaruhi atau merubah orang lain agar bertindak sesuai dengan apa yang dikehendaki dengan atau tanpa melalui media. Komunikasi akan dapat berhasil baik apabila sekiranya timbul saling pengertian, yaitu jika kedua belah pihak si pengirim dan si penerima pesan dapat memahami. Hal ini tidak berarti bahwa keduanya harus menyetuji suatu gagasan tersebut. Yang terpenting adalah kedua pihak sama-sama memahami gagasan tersebut. Maka dalam hal inilah dapat dikatakan bahwa komunikasi telah berhasil.

\section{Tujuan dan Fungsi Komunikasi}

a. Tujuan Komunikasi

Menurut Astrid S. Susanto dalam Yoyon Mudjiono, Ia menegaskah bahwa tujuan akhir komunikasi adalah pembentukan kepribadian, perlunya pendidikan untuk penduduk dewasa dan remaja (adult education atau nonformal education) adalah tidak lain daripada itu adalah penggunaan suatu ilmu pengetahuan baru dari orang lainyang akan bertindak dengan bijaksana, sehingga terbentuklah manusia bijaksana. ${ }^{9}$

Dengan kata lain, komunikasi sebagai alat untuk mengenalkan diri pada lingkungannya, sehingga orang lain dapat mengukur dan mengetahui seberapa eksistensi dirinya terhadap lingkungannya. Hal ini dapat di tarik kesimpulan bahwa tujuan komunikasi adalah untuk mengharapkan pengertian, dukungan gagasan dan tindakan yang seseorang lakukan dari orang lain untuk mengubah sikap pendapat dan perilaku. 
b. Fungsi Komunikasi

$$
\text { Apabila }
$$

komunikasi

dipandang dari arti yang lebih luas, tidak hanya diartikan sebagai pertukaran berita dan pesan, tetapi sebagai kegiatan individu dan kelompok mengenai tukarmenukar data, fakta, dan ide maka fungsinya dalam setiap sistem sosial adalah sebagai berikut ${ }^{10}$ :

1) Informasi : pengumpulan, penyimpanan, pemrosesan, penyebaran berita, data, gambar, fakta dan pesan opini, dan komentar yang dibutuhkan agar dapat dimengerti dan beraksi secara jelas terhadap kondisi lingkungan dan orang lain agar dapat mengambil keputusan yang tepat.

2) Sosialisasi (pemasarakatan) : penyediaan sumber ilmu pengetahuan yang memungkinkan orang bersikap dan bertindak sebagai anggota masyarakat yang efektif sehingga ia sadar akan fungsi sosialnya sehingga ia dapat aktif didalam masyarakat.

3) Memberi motivasi : menjelaskan tujuan setiap masyarakat jangka pendek maupun jangka panjang, mendorong orang menentukan pilihannya dan keinginannya, mendorong kegiatan individu dan kelompok berdasarkan tujuan bersama yang akan dikejar.

4) Perdebatan dan diskusi : menyediakan dan saling menukar fakta yang diperlukan untuk memungkinkan persetujuan atau menyelesaikan perbedaan pendapat mengenai masalah publik, menyediakan bukti-bukti yang relevan yang diperlukan untuk kepentingan umum agar masyarakat lebih melibatkan diri dalam masalah yang menyangkut kepentingan bersama di tingkat nasional dan lokal.

5) Pendidikan : pengalihan ilmu pengetahuan sehingga mendorong perkembangan intelektual, pembentukan watak dan pendidikan keterampilan dan kemahiran yang diperlukan pada semua bidang kehidupan.

6) Memajukan kebudayaan : penyebaran hasil kebudayaan dan seni dengan maksud melestarikan warisan masa lalu, perkembagan kebudayaan dengan memperluas horizon seseorang, membangun imajinasi dan mendorong kreatifitas dan kebutuhan estetika. 
7) Hiburan : penyebarluasan sinyal, simbol, suara dan gambar dari drama, tari kesenian, kesusastraan, musik dan olah raga, permainan dan lain-lain untuk rekreasi, kesenagan kelompok dan individu.

8) Integrasi : menyediakan bagi bangsa, kelompok dan individu kesempatan untuk memperoleh berbagai pesan yang mereka perlukan agar mereka dapat saling kenal dan mengerti serta menghargai kondisi, pandagan dan keinginan orang lain.

Dapat diketahui bahwa fungsi komunikasi merupakan fungsionalisasi dalam meningkatkan kebutuhan dan kesejahteraan manusia. Dari kebutuhan ini komunikasi berfungsi sebagai penyampaian isi pernyataan seseorang supaya orang lain sependapat, seperasaan dan selangkah dengannya.

\section{Proses Komunikasi}

Proses Komunikasi adalah suatu proses kelangsungan yang berkesinambungan, komunikasi dapat dikatakan proses apabila dalam kelangsungan terdapat seseorang yang menyampaikan suatu pesan atau informasi terntu, dan ada seseorang yang menerima pesan tersebut. Maka dari itu Onong mengkategorikan proses komunikasi menjadi dua prespektif, yaitu $^{11}$ :

1) Proses komunikasi dalam prespektif psikologis

Proses komunikasi prespektif ini terjadi pada diri komunikator dan komunikan. Ketika seorang komunikator berniat akan menyampaikan suatu pesan kepada komunikan maka dalam dirinya terjadi suatu proses, yaitu proses "pengemasan" atau "membungkus" pikiran dengan bahasa yang dilakukan komunikator itu, dalam bahasa komunikasi dinamakan encoding. Hasil dari encoding berupa pesan itu, kemudian ia transmisikan atau operkan atau kirimkan kepada komunikan.

2) Proses komunikasi dalam prespektif mekanistik

Proses ini berlangsung ketika komunikator mengoperkan atau "melemparkan" dengan bibir jika lisan, atau tangan jika tulisan, pesannya sampai ditangkap oleh komunikan. Penangkapan pesan dari komunikator oleh komunikan itu dapat dilakuakan berupa dengan, indera telinga, indera mata, atau indera-indera lainnya. Proses komunikasi ini kompleks atau rumit, sebab bersifat situasional, bergantung pada situasi ketika komunikasi itu berlangsung.

${ }^{11}$ Onong Uchjana Effendi, Ilmu Komunikasi, 31-32. 
Tentu saja dalam proses komunikasi terdapat unsur-unsur yang menunjang proses komunikasi berjalan dengan baik. Paling sedikit terdapat tiga unsur, dua diantaranya manusia, yang satunya adalah pesan. Apabila orang-orang yang terlibat dalam komunikasi itu berada di jarak yang jauh tempatnya atau banyak jumlahnya, maka bertambahlah unsur komunikasi, dengan adanya sebuah sarana untuk menyambung pesan tersebut kepada seseorang atau banyak orang yang merupakan sasaran komunikasi tersebut.

Persyaratan terjadinya proses komunikasi, harus mempunyai komponen-komponen yang mendukung, berikut lima komponen dalam proses komunikasi yaitu : Komunikator, pesan, komunikan, media, efek. Jadi proses komunikasi adalah pengoperan dan penerimaan pesan yang telah dirumuskan komunikator untuk disampaikan kepada komunikan dengan atau tanpa menggunakan media atau saluran untuk tujuan tertentu dan diharapkan adanya dampak dari pesan tersebut.

\section{Pola-Pola Komunikasi}

Pola komunikasi merupakan sebuah model dari proses komunikasi, sehingga dengan adanya beraneka ragam model komunkasi dan bagian dari proses komunikasi akan dapat ditemukan pola yang cocok dan mudah 33.

12 Onong U Effendy, Dinamika Komunikasi,

${ }^{13}$ Sylvia Moss dan Stewart L. Tubbs, Human Communication. (Bandung: PT. Yayasan Andi, 2001), 26. di gunakan dalam berkomunikasi. Pola komunikasi identik dengan proses komunikasi, karena pola komunikasi merupakan rangkaian dari aktivitas menyampaikan pesan sehingga diperoleh feedback dari penerima pesan, dari proses komunikasi, akan timbul pola, model, bentuk dan juga bagianbagian kecil yang berkaitan erat dengan proses komunikasi. ${ }^{12}$

Tubbs dan Moss mengatakan bahwa "Pola komunikasi atau hubungan itu dapat dicirikan oleh : komplementaris atau simetris. Dalam hubungan komplementer satu bentuk perilaku dominan dari satu partisipan mendatangkan perilaku tunduk dan lainnya. Dalam simetri, tingkatan sejauh mana orang berinteraksi atas dasar kesamaan. Dominasi bertemu dengan dominasi atau kepatuhan dengan kepatuhan". ${ }^{13}$

Sedangkan menurut Effendy, pola komunikasi adalah proses yang dirancang untuk mewakili kenyataan keterpautannya unsur-unsur yang dicakup beserta keberlangsungannya, guna memudahkan pemikiran secara sistematis dan logis. ${ }^{14}$

Jadi pola komunikasi merupakan bentuk atau gambaran hubungan komunikator dengan komunikan dalam proses komunikasi dengan mengaitkan komponen-komponen yang merupakan bagian penting atas terjadinya suatu 30.

${ }^{14}$ Onong U Effendy, Dinamika Komunikasi, 
hubungan. Adapun pola komunikasi dan penjelasannya sebagai berikut :

a. Pola Komunikasi Primer

Pola ini merupakan suatu proses penyampaian pikiran oleh komunikator kepada komunikan dengan menggunakan suatu simbol sebagai media atau saluran. Pola komunikasi ini kemudian dikenal dengan nama komunikasi primer yaitu komunikasi dengan menggunakan lambang atau bahasa sebagai sarana utamanya, sedangkan lambang nonverbal digunakan dalam proses komunikasi dengan menggunnakan anggota badan yang meliputi bibir, kepala, tangan, dan jari. $^{15}$

\section{b. Pola Komunikasi Sekunder}

Pola komunikasi sekunder adalah proses penyampaian pesan oleh seseorang kepada orang lain dengan menggunakan alat atau sarana sebagai media kedua setelah memakai lambang sebagai media media pertama. Komunikator menggunakan media kedua ini karena komunikan yang dijadiakn sarana komunikasinya jauh tempatnya, atau banyak jumlahnya atau kedua-duanya, jauh dan banyak. Komunikasi dalam proses secara sekunder ini semakin lama semakin efektif dan efesien karena didukung oleh teknologi komunikasi yang semakin canggih, yang ditopang pula

${ }^{15}$ Hafied Cangara, Pengantar Ilmu Komunikasi, (Jakarta: Raja Grafindo Persada, 1998), 45. oleh teknologi-teknologi lainnya yang bukan teknologi komunikasi. ${ }^{16}$

Tidak hanya komunikasi massa yang menggunakan pola komunikasi ini, namun tipe komunikasi organisasi juga dapat menerapkan pola komunikasi sekunder, karena dengan pola komunikasi sekunder dapat menerapkan komunikasi yang bersifat terbuka sehingga dapat dengan mudah melakukan komunikasi dengan berbagai macam hirarki dalam organisasi tersebut

c. Pola komunikasi Linear

Komunikasi tatap muka, baik komunikasi antar pribadi (interpersonal communication) maupun komunikasi kelompok (group communication) meskipun memungkinkan terjadinya dialog, tetapi ada kalanya berlangsung linear. Pola komunikasi linear umumnya berlangsung pada komunikasi bermedia, kecuali komunikasi melalui media telepon. Komunikasi melalui media telepon hampir tidak pernah berlangsung linear, melainkan dialogis, tanya jawab dalam bentuk percakapan. Komunikasi linear dalam prakteknya hanya ada pada komunikasi bermedia, tetapi dalam komunikasi tatap muka juga dapat dipraktekkan, yaitu apabila komunikasi pasif. ${ }^{17}$

\footnotetext{
${ }^{16}$ Dedy Mulyana, Ilmu Komunikasi Suatu Pengantar (Bandung: PT Remaja Rosdakarya, 2010), 260-261.

${ }^{17}$ Hafied Cangara, Pengantar Ilmu, 39.
} 
d. Pola komunikasi Sirkular

Pola komunikasi sirkular ini didasarkan pada prespektif interaksi yang menekankan bahwa komunikator atau sumber respon secara timbal balik pada komunikator lainnya. Prespektif interaksional ini menekankan tindakan yang bersifat simbolis dalam suatu perkembangan yang bersifat proses dari suatu komunikasi manusia. Dalam pola komunikasi sirkular, mekanisme umpan balik dalam komunikas dilakukan antara komunikator dan komunikan saling mempengaruhi (interplay) antara keduanya yaitu sumber dan penerima. Osgood bersama Schram pada tahun 1954 menentukan peranan komunikator dan penerima sebagai pelaku utamakomunikasi. Berikut pola komuniksi sirkular digambarkan oleh Schram. ${ }^{18}$

\section{Komunikasi Kelompok}

Kelompok adalah sekumpulan orang yang mempunyai tujuan bersama, yang berinteraksi satu sama lain untuk mencapai tujuan bersama, mengenal satu sama lainnya, dan memandang mereka sebagai bagian dari kelompok tersebut. Kelompok ini misalnya adalah keluarga, kelompok pemecah masalah, atau suatau keputusan. Komunikasi kelompok biasanya merujuk pada komunikasi

\footnotetext{
${ }^{18}$ Muhammad Arni, Komunikasi Organisasi, (Jakarta: Bumi Aksara, 20014), 41.

${ }^{19}$ Deddy Mulyana, Ilmu Komunikasi , 82.
}

yang dilakukan kelompok kecil (small group communication).$^{19}$

Jadi komunikasi kelompok adalah interaksi tatap muka yang terdiri dari dua atau lebih individu yang dapat mempengaruhi satu sama lain untuk tujuan yang sama.

\section{Komunikasi Interpersonal}

Pentingnya situasi komunikasi antar pribadi ialah karena prosesnya memungkinkan berlangsung secara dialogis (dialogical communication) yaitu situasi yang berlangsung bentuk dialog atau percakapan. Komunikasi yang berlangsung secara dialogis selalu lebih baik daripada secara monologis. Monolog menunjukkan suatu bentuk komunikasi dimana seseorang bicara, sedangkan yang lain hanya mendengarkan, jadi tidak ada interaksi antara mereka. Yang aktif hanya komunikator saja sedangkan komunikan pasif. ${ }^{20}$ Jadi, Komunikasi antarpersonal (interpersonal communication) adalah komunikasi yang terjadi antara komunikator dengan satu orang atau beberapa komunikan.

Pentingnya situasi komunikasi antar pribadi ialah karena prosesnya memungkinkan berlangsung secara dialogis (dialogical communication) yaitu situasi yang berlangsung bentuk dialog atau percakapan.dan juga pentingnya bagi komunikator ialah agar ia dapat mengetahui komunikan

\footnotetext{
${ }^{20}$ Onong Uchjana Effendi, Ilmu Teori, 60.
} 
dengan selengkap-lengkapnya artinya untuk mengubah sikap, pendapat, atau perilakunya. Dengan demikian komunikator dapat mengarahkannya ke suatu tujuan sebagaimana ia inginkan.

\section{Masyarakat Marginal}

Marginalisasi adalah fenomena ketidak seimbangan dalam pemerolehan peluang dalam aspek ekonomi, sosial dan pendidikan oleh sekumpulan masyarakat, semua dapat terjadi dari berbagai faktor yang saling berkaitan. Akibat dari marginalisasi inilah, masyarakat menjadi miskin dan berada dalam keadaan serba kekurangan entah itu dari finansial ataupun dari moral dan pendidikan.

Melalui marginalisasi ini, segala sesuatu yang berasal kelompok sasaran dianggap buruk dan berpotensi memberikan kontribusi negatif atas proses-proses sosial yang berlangsung. Dengan anggapan ini maka tindakan dan perilaku kelompok marginal dianggap tidak bermakna atau bahkan harus dihindari agar akses-akses negatif yang mungkin ditimbulkannya bisa diantisipasi. Bahkan perilaku yang sesungguhnya bernuansa positif bisa dianggap buruk melalui penggambaran-penggambaran yang tidak sesuai dengan fakta sesungguhnya. ${ }^{21}$

Masyarakat marginal ini mendapat peluang terbatas akibat keadaan mereka dalam beberapa aspek yang akhirnya memberikan kesan negatif kepada hasil kemajuan negara. Konsep marginalisasi juga dapat dikaitkan dengan fenomena penyingkiran sosial yang berlaku karena ketidakseimbangan dalam program pembangunan masyarakat dan juga peluang pendidikan yang tidak menyeluruh. Kenyataanya masyarakat marginal seringkali dikaitkan dengan kemiskinan dan hidup serba kekuranyan. Demi menampung keperluan, mereka mempunyai kecenderungan untuk terlibat dalam kegiatan yang tidak bermoral, menyalahi etika dan norma, seperti terlibat dalam pemakaian dan pengedaran narkoba, meminum minuman keras, bahkan PSK .

Pola pikir masyarakat marginal dipengaruhi oleh situasi-situasi psikososial yang memposisikannya berperilaku di luar aktivitas pada umumnya. Perilaku ini yang sering diistilahkan dengan tidak beradab dan tidak beretika. Labelisasi ini terus menerus berlangsung sehingga menjadi salah satu pembentuk karakter yang cukup berpengaruh bagi masyarakat marginal. Proses marginalisasi ini kemudian berpengaruh bagi terciptanya kondisikondisi sosial kelompok yang diposisikan terpinggir.

Masyarakat marginal yang telah dipinggirkan merupakan ciri-ciri utama marginalisasi. Marginalisasi yang dihadapi oleh masyarakat marginal ini saling berkaitan. Sebagai contoh, apabila seseorang telah

\footnotetext{
${ }^{21}$ Eriyanto, Analisis Wacana, $125 .$.
} 
mengalami marginalisasi pendidikan berkemungkinan besar mereka juga menghadapi marginalisasi dalam pekerjaan, marginalisasi dari masyarakat umun dan marginalisasimarginalisasi lain.

Jadi, masyarakat marginal adalah masyarakat yang terpinggirkan atau disisihkan oleh beberapa orang, sehingga masyarakat marginal sering mendapatkan tindak kekerasan berupa ucapan maupun tindakan dari masyarakat yang mempunyai status sosial lebih tinggi.

\section{Metode Penelitian}

Metode penelitian yang digunakan dalam penelitian ini adalah deskriptif kualitatif. Dimana peneliti mendeskripsikan pola dan proses komunikasi yang berlangsung antara Urban Care Community (UCC) dengan masyarakat marginal Stren Kali Jagir, Surabaya. Pengumpulan data dilaksanakan dengan (1) Wawancara bersama beberapa informan yang sesuai penelitian ini, (2) Observasi pada kegiatan UCC dan lingkungan pemukikan kampong Stren Kali Jagir Surabaya, dan (3) Dokumentasi. Data yang didapat menggunakan analisis interaktif. Dalam analisis ini, data yang diperoleh dilapangan disajikan dalam bentuk narasi. Sedangkan untuk mendapatkan keabsahan data dilakukan uji coba kredibilitas dengan cara Triangulasi data.

\section{Hasil dan Pembahasan}

1. Proses Komunikasi Urban Care Community dengan masyarakat marginal Stren Kali Jagir Surabaya

Proses komunikasi yang berlangsung antara anggota komunitas UCC dengan masyarakat marginal Stren Kali Jagir Surabaya menggunakan komunikasi antar pribadi bersifat diadik (Dyadic communication) yaitu komunikasi antar pribadi yang berlangsung antar dua orang yaitu komunikator dengan komunikan melalui tatap muka. Komunikasi antar pribadi ini berjalan sangat efektif sehingga kedekatan UCC dengan masyarakat marginal Stren Kali Jagir terjalin sangat akrab

. Terbukti ketika komunitas UCC pertama kali masuk kedalam kampung Stren Kali Jagir, dengan keadaan mereka tidak diterima, namun setelah melakukan pendekatan dengan menggunakan proses komunikasi interpersonal yang mereka lakukan, sekarang anggota UCC mempunyai citra yang baik bahkan dianggap seperti keluarga sendiri dengan masyarakat marginal Stren Kali Jagir Surabaya.

Dengan menggunakan komunikasi interpersonal mereka dapat membangun hubungan emosional dan keakraban baik secara verbal maupun nonverbal dengan masyarakat marginal Stren Kali Jagir, nampak dari cara mereka berkomunikasi, seperti saat anggota UCC mengajak anak-anak Stren Kali Jagir agar mau ikut kegitan Ayo Belajar di hari sabtu dengan 
mendatangi rumah mereka satu per satu.

Mereka menggunakan komunikasi verbal yang efektif seperti dengan intonasi berbicara yang halus merayu mereka dengan sabar untuk berusaha mengajak adik-adik agar ikut kegiatan tersebut, dan ketika kegiatan belajar berlangsung, kakak-kakak UCC mengajar adik-adiknya dengan ceria dan bersemangat, sehingga adikadiknya merasa senang dan nyaman belajar bersama komunitas UCC.

Tidak hanya secara verbal saja, bahkan dari komunikasi nonverbal yang terjalin secara langsung atau antar pribadi ini berjalan efektif seperti saat adik-adik meminta dipangku, dipeluk, diperhatikan dan bermanja-manja dengan kakak-kakak UCC, kedekatan seperti ini dilalui dengan komunikasi antar pribadi, sehingga kedekatan antara komunikator dan komunikan terjalin secara emosional, sehingga mereka tidak segan untuk membuka dirinya, bercerita dan berkeluh kesah dengan anggota UCC.

Dalam sebuah komunitas tentu saja akan ada komunikasi kelompok, guna menyatukan tujuan sebuah komunitas. Untuk mewujudkan tujuannya tentu saja UCC membutuhkan strategi dan upaya yang harus mereka diskusikan melalui komunikasi kelompok. Proses komunikasi kelompok seperti ini juga lebih efesien dalam menyampaikan pesan untuk membangun kedekatan dengan masyarakat Stren Kali Jagir, walaupun harus melalui diskusi yang mereka lakukan setiap satu bulan sekali di dalam kajian parenting ataupun evaluasi kegiatan dalam komunitas UCC.

Kegiatan ini dilakasanakan bertujuan untuk menyelaraskan ide dan gagasan setiap individunya. Penyelarasan ide ini bertujuan agar saat anggota komunitas UCC melakukan proses komunikasi memiliki satu tujuan yang sama. Peneliti melihat komunikasi kelompok yang terjalin dalam komunitas UCC memiliki hubungan yang intensif di antara satu anggota dengan anggota lainnya. Keakraban antar anggota sangat nampak sekali ketika peneliti melihat mereka rapat, mengobrol bahkan bercanda. Seperti tidak ada batasan jabatan diantara mereka.

Komunitas UCC juga menggunakan media sosialyaitu Whatsapp yang berfungsi sebagai wadah komunikasi yang efesien bagi komunitas UCC. Dengan berkomunikasi melalui media sosial, komunitas UCC merasa termudahkan dalam menginformasikan sesuatu dan berkomunikasi dengan sesama anggota UCC, anak-anak maupun waraga disana, sehingga kedekatan yang terjalin antara anggota komunitas dengan masyarakat tidak terputus dan tetap berjalan dengan baik.

Proses komunikasi Urban Care Community dengan masyarakat marginal Stren Kali Jagur, Surabaya lebih sering menggunakan komunikasi antar pribadi yang bersifat diadik atau tatap muka. Ada juga komunikasi kelompok yang dilakukan untuk 
menyelaraskan gagasan ataupun tujuan UCC dan dengan menggunakan komunikasi lewat media sosial Whatsapp membuat proses komunikasi menjadi semakin akrab antara UCC dengan masyarakat marginal Stren Kali Jagir, Surabaya, sehingga masyarakat dapat terbuka dan menerima kedatangan anggota UCC dengan senang hati.

\section{Pola Komunikasi Urban Care} Community dengan masyarakat marginal Stren Kali Jagir Surabaya

Pola komunikasi yang terbentuk pada komunitas UCC, yakni melalui proses komunikasi antar pribadi dalam menyampaikan pesan kepada masyarakat marginal Stren Kali Jagir, baik secara verbal yaitu dengan menggunakan kata-kata dan bahasa yang lembut dalam mengajak masyarat untuk ikut serta dalam kegiatan, ataupun secara nonverbal, yaitu dengan merangkul dan memangku adik-adik ketika belajar bersama, ataupun dengan memberikan bingkisan kepada masyarakat agar mereka tertarik dengan kegiatan komunitas UCC sehingga dapat dekat dan akrab dengan masyarakat marginal Stren Kali Jagir.

Dengan didukung media komunikasi yang canggih sekarang ini membuat komunikasi yang mereka jalin semakin efektif. hanya dengan menggunakan media sosial Whatsapp, mereka dengan mudahnya dapat berkomunikasi, sehingga komunikasi yang terjalin akan tetap akrab antara anggota komunitas UCC dengan masyarakat Stren Kali Jagir Surabaya.

Menurut analisis peneliti, pola komunikasi yang terbentuk pada komunitas Urban Care Community ini adalah pola komunikasi sekunder yakni proses penyampaian pesan oleh anggota komunitas UCC kepada masyarakat marginal Stren Kali Jagir Surabaya dengan menggunakan alat atau sarana sebagai media komunikasi seperti Whatsapp, setelah mereka memakai lambang, yang bisa berupa bahasa maupun tingkah laku dalam penyampaian pesan secara langsung sebagai media pertama. Komunitas UCC menggunakan media kedua ini, karena masyarakat yang dijadikan sasaran komunikasinya jauh tempatnya dan banyak jumlahnya sehingga untuk menjaga hubungan komunikasi tetap baik mereka menggunakan grup Whatsapp yang dianggap lebih efsien. Karena komunikasi dengan pola sekunder ini semakin lama semakin efektif dan efesien karena didukung oleh teknologi komunikasi yang semakin canggih.

Dengan pola komunikasi sekunder yang digunakan UCC dengan masyarakat marginal Stren Kali Jagir, Surabaya membuat komunikasi antara mereka berjalan lancar dan semakin dekat terbukti dengan banyaknya masyarakat yang masih aktif mengikuti kegiatan.

Tindakan sosial yang dilakukan anggota komunitas UCC dengan masyarakat marginal Stren Kali Jagir 
memiliki hubungan timbal balik diantaranya, tidak hanya barang atau jasa yang diberikan kepada masyarakat, melainkan melalui ide atau gagasan untuk memotivasi mereka sehingga muncul inovasiinovasi baru dalam merubah pola pikir dan tingkah laku mereka lewat sistem pendidikan masyarakat yang notabennya mereka tidak memiliki ruang gerak yang cukup luas seperti masyarakat pada umumnya.

Tidak hanya ide dan gagasan, namun pertukaran komunikasi secara emosional yang dibentuk lewat komunikasi antar pribadi juga terbentuk dalam komunitas UCC, melalui program kegiatan Ayo Belajar dan Ayo Mengaji yang dilakukan UCC dengan masyarakat membuat pesan emosional tersampaikan, sehingga terjadi timbal balik, seperti ketika masyarakat marginal Stren Kali Jagir terbuka untuk bercerita tentang keadaannya, atau pengalamannya dengan anggota komunitas UCC atau ketika pemenuhan kasih sayang yang diharapkan anak-anak Stren Kali Jagir kepada anggota komunitas UCC terlaksana, sehingga anak-anak terkadang ingin dimanja, bahkan mencari perhatian, dan ada juga yang duduk disamping dan diam seakanakan minta diperhatikan, keadaan seperti ini tercipta karena kurangnya kasih sayang yang mereka rasakan dari orang tuanya.

Sumber daya yang dimaksud disini tidak harus dikaitkan dengan materi, bisa juga berupa perhatian, kasih sayang, rasa kekelurgaan, dan rasa nyaman yang diberikan anggota komunitas UCC kepada anak-anak Stren Kali Jagir Surabaya sehingga kedekatan secara emosional yang dibangun berjalanan cukup erat. Dan menurut informan pertama yaitu Muhammad Lutfi ketika peneliti mewawancarainya, dia mengatakan bahwa timbal balik yang diterima teman-teman UCC dari masyarakat yaitu dengan melihat masyarakat selalu terbuka dengan anggota UCC, peduli dengan pendidikan dan mendukung penuh kegiatan komunitas UCC itu sudah cukup baginya.

\section{Kesimpulan}

Berdasarkan data penelitian dan analisis data yang telah diuraikan, maka penelitian peneliti menyimpulkan bahwa, Proses komunikasi berlangsung secara diadik atau tatap muka yang dilakukan komunitas Urban Care Comunnity (UCC) menggunakan proses komunikasi antar pribadi, komunikasi kelompok, dan menggunakan media sosial seperti Whatsapp juga dilakukan sebagai pendukung komunitas UCC dalam menjaga dan mempererat hubungan antara anggota komunitas dengan masyarakat marginal Stren Kali Jagir Surabaya.

Pola komunikasi yang terbentuk pada komunitas Urban Care Community ini adalah pola komunikasi sekunder yakni proses penyampaian pesan oleh anggota komunitas UCC kepada masyarakat marginal Stren Kali Jagir Surabaya dengan menggunakan alat atau sarana sebagai media komunikasi seperti Whatsapp, 
setelah mereka memakai lambang, yang bisa berupa bahasa maupun tingkah laku dalam penyampaian pesan secara langsung sebagai media pertama. Komunitas UCC menggunakan media kedua ini karena masyarakat yang dijadikan sasaran komunikasinya jauh tempatnya dan banyak jumlahnya sehingga untuk menjaga hubungan komunikasi tetap baik mereka menggunakan group whatsapp yang dianggap lebih efisien.

\section{Daftar Pustaka}

Arni, Muhammad. Komunikasi Organisasi. Jakarta: Bumi Aksara, 2014.

Azwar, Saifuddin. Metode Penelitian. Yogyakarta: Pustaka Pelajar, 1998.

Bungin, Burhan. Penelitian Kualitatif: Komunikasi, Ekonomi, Kebijakan Publik, dan Ilmu Sosial Lainnya. Jakarta: Putra Grafika, 2007.

Bungin, Burhan. Sosiologi Komunikasi: Teori, Paradigma, dan Diskursus Teknologi Komunikasi di Masyarakat. Jakarta: Kencana, 2006.

Cangara, Hafied. Pengantar Ilmu Komunikasi. Jakarta: Raja Grafindo Persada, 1998.

Eriyanto. Analisis Wacana, Pengantar Analisis Teks Media. Yogyakarta: LKiS, 2001.

Goldberg, Alvin A,Carl E. Larson. Komunikasi Kelompok. Jakarta: UIPress, 1985.

Haryanto, Sindung. Spektrum Teori Sosial. Yogjakarta: Ar-Ruzz Media, 2012.
Mille, Matthew B. dan A. Michael Huberman, Analisis data Kualitatif: Buku Sumber Tentang Metode-metode Baru. Jakarta: UI Pers, 1992.

Moleong, Lexy J. Metodologi Penelitian Kualitatif. Bandung: PT. Remaja Rosydakarya, 2004.

Moss, Sylvia dan Stewart L. Tubbs. Human Communication. Pengantar: Dr. Deddy Mulyana. Bandung: PT. Yayasan Andi, 2001.

Mudjiono, Yoyon. Ilmu Komunikasi. Surabaya: Jaudar Press, 2015.

Mulyana, Deddy dan Jalaluddin Rahmat. Komunikasi Antar Budaya Panduan Berkomunikasi Dengan Orang-orang Berbeda Budaya. Bandung: PT Remaja Rosdakarya, 2016.

Mulyana, Deddy Ilmu Komunikasi Suatu Pengantar. Bandung: PT. Remaja Rosdakarya, 2007.

Novia, Windy. Kamus Populer Ilmiah. Jakarta: Wacana Intelektual, 2008.

Nurdin, Ali. Komunikasi Kelompok dan Organisasi. Surabaya: UIN Sunan Ampel Press, 2014.

Rakhmat, Jalaludin. Psikologi Sosial. Jakarta: PT. Remaja Rosdakarya, 2001.

Setyadi , Elly M. (dkk). Ilmu Sosial dan Budaya Dasar. Jakarta: Kencana Penanda Media group, 2007.

Uchjana, Onong Effendy. Dinamika Komunikasi. Bandung: PT. Remaja Rosdakarya, 1993. 
Uchjana, Onong Effendy. Ilmu komunikasi

Teori Dan Praktek. Bandung: Remaja Rosdakarya, 2009.

Vardiansyah, Dani. Pengantar Ilmu Komunikasi. Bogor: Ghalia Indonesia, 2004.

Widjaja, A. W. Komunikasi dan Hubungan Masyarakat. Jakarta: Bumi Aksara, 1993.

Wirawan, I.B. Teori-Teori Sosial. Jakarta: Kencana, 2013. 